\title{
Microwave irradiated coconut shell-activated carbon for decolourisation of palm oil mill effluent (POME)
}

\author{
${ }^{1,3}$ Abdulsalam, M., ${ }^{1 *}$ Hasfalina, C.M., ${ }^{2}$ Mohamed, H.A., ${ }^{2}$ Abd Karim, S.F. and \\ ${ }^{2}$ Faiez, M.S. \\ ${ }^{1}$ Department of Biological and Agricultural Engineering, Faculty of Engineering, Universiti Putra \\ Malaysia, 43400, UPM Serdang, Selangor, Malaysia. \\ ${ }^{2}$ Department of Chemical Engineering, Faculty of Engineering, Universiti Teknologi Mara, Malaysia \\ ${ }^{3}$ Department of Agricultural and Bioresources Engineering, Faculty of Engineering, Ahmadu \\ Bello University, Zaria, Nigeria
}

\author{
Article history: \\ Received: 21 May 2018 \\ Received in revised form: 6 \\ Aug 2018 \\ Accepted: 8 Aug 2018 \\ Available Online: 6 \\ November 2018 \\ Keywords: \\ Coconut Shell, \\ Activated Carbon, \\ Microwave, \\ Decolourization, \\ POME, \\ Adsorption Isotherms \\ DOI: \\ https://doi.org/10.26656/fr.2017.2(6).103
}

\begin{abstract}
The study was based on the adsorption principle of colour removal from POME using natural bio-sorbents Coconut Shell activated carbon (CS-AC) pre-treated by microwave irradiation. The effect of operating parameters such as $\mathrm{pH}$, adsorbent dosage, and contact time was varied at different ranges: $2-8.5 ; 1-6 \mathrm{~g}$ and 1-8 hrs, respectively. It was observed that colour adsorption increased with increase in contact time. The maximum uptake of colour by the adsorbents occurred at $\mathrm{pH} 2$. Also, the maximum percentage of colour removal of $95 \%$ was obtained at the optimum conditions for coconut shell-microwave (CS -MW) of $5 \mathrm{~g} / 100 \mathrm{~mL}$ dosage, $5 \mathrm{hrs}$ contact time and $\mathrm{pH}$ 2. The Freundlich and Langmuir isotherm linear model showed a strong correlation with the experimental data with an $\mathrm{R}^{2}$ value of 0.9175 and 0.9892 for each of the respective model. This implies that the Langmuir isotherm model gave a better fit as indicated by the $\mathrm{R}^{2}$ value. It can be concluded that the CSAC has a potential to be used as bio-sorbent for POME decolourization.
\end{abstract}

\section{Introduction}

The development of palm oil processing industry in Malaysia has led the country to become one of the largest exporters of palm oil produce in the world (Din, 2017). According to Malaysian Palm Oil Board (MPOB), as of December 2012, there were 429 palm oil processing industries which have fascinated several economic values such as national revenue, industrialization and job opportunities. However, the intense industrial palm oil processing and extraction have also resulted in the generation of a large quantity of palm oil mill effluent (POME) into the environment (Sumathi et al., 2008). Also, a report has shown that the generated POME is loaded with organic pollutants such as chemical oxygen demand (COD) and biochemical oxygen demand (BOD) (Embrandiri et al., 2015). Therefore, discharging such waste into waterways without appropriate treatment have a negative impact on the ecosystem of the aquatic life's (Hashim et al., 2017). Though, considerable efforts have been placed towards mitigating the adverse effect by reducing the pollutants concentration using different treatment approaches such as membrane technology (Subramaniam et al., 2017; Tan et al., 2017) microbial fuel cells (Baranitharan et al., 2015; Tee et al., 2016; Neoh et al., 2017) decomposition by oxidation process ( Saeed et al., 2015; Parthasarathy et al., 2016), coagulation and adsorption process using activated carbon (Mohammed and Chong, 2014; Othman et al., 2014; Alkhatib et al., 2015; Tabassum et al., 2015).

Noticeably, among the aforementioned treatments approaches, adsorption process using activated carbon have been reported most efficient, less demanding in terms of operation and cost-effective for removing the carcinogenic dark brownish colour substances such as the phenolic and melanoidin compounds present in POME (Demirbas, 2008; Ghaedi et al., 2012; Kismir and Aroguz, 2011). Adsorption treatment method for POME decolourization using activated carbon has received considerable efforts which yielded significant achievements in the last two decades. Mohammed and Chong (2014) use palm kernel shell activated carbon to decolourize POME under variable contact time, $\mathrm{pH}$ and adsorbent dosage. The authors reported that $\mathrm{pH}$ has a significant effect on decolourization performance and that almost $100 \%$ colour removal was archived at a $\mathrm{pH}$ 
value of 2. Equally, Alkhatib et al. (2015) optimize colour removal from POME using granular activated carbon and $89.95 \%$ decolourization was archived. Essentially, both studies indicated that reducing the $\mathrm{pH}$ level of the treating sample has a significant effect on the rate at which the adsorbate (colour compound) adheres to the active site of the activated carbon. In another application, Azmi and Yunos (2012) and Amosa et al. (2016) investigated the performance of coconut shell activated carbon to alleviate turbidity and suspended solids from POME. From the respective studies, 4.50 NTU, $71.26 \%$ and $89.1 \%, 91.4 \%$ removal efficiencies were reported. Furthermore, Adeleke et al. (2017) optimize removal of $\mathrm{COD}$ and $\mathrm{NH}_{3}-\mathrm{N}$ from POME using powdered cow bone activated carbon. At optimal condition of $\mathrm{pH} 10,125 \mathrm{~g} / \mathrm{L}$ dosage and $2 \mathrm{hrs}$ contact time, a significant $\mathrm{COD}$ and $\mathrm{NH}_{3}-\mathrm{N}$ removal efficiency were observed with $89.60 \%$ and $75.61 \%$, respectively. Recently, bio-sorbent developed from oil palm residue was used to relegate the COD and suspended solids concentration with $70.38 \%$ and $95.38 \%$ efficiency at 150 rpm agitation for a period of $24 \mathrm{hrs}$ contact time (Ibrahim et al., 2017). In recaps, from the above literature, it is obvious that the adsorption treatment of POME by activated carbon is not only suitable for colour removal but also have the capacity to adsorb other contaminants. Though, it is a worthy note that the adsorption performance has a strong correlation with the procedures and methods used for the carbonization and activation of the char (coconut shell) which could invariably influence the nature of the final morphology of the resulted activated carbon (Tan et al., 2008; Basta et al., 2009).

Most of the activated carbon used in the studies reported above was prepared using conventional methods (physical or chemical activation) for carbonization and activation of the carbonaceous precursor. This method is demanding in terms of temperature requirement, excessive energy consumption and longer activating time (Gautam et al., 2014). While, the chemical method involves impregnation of the carbonaceous coconut shell with dehydrating chemical reagents such as $\mathrm{H}_{2} \mathrm{SO}_{4}$, $\mathrm{KOH}, \mathrm{NaOH}, \mathrm{ZnCl}_{2}, \mathrm{~K}_{2} \mathrm{CO}_{3}$ or $\mathrm{H}_{3} \mathrm{PO}_{4}$ to carbonize and activate the precursor at lower activation temperature, time and energy consumption. Compared to the former, the better porous structure is usually obtained using the chemical method of activation. However, the major limitation of this method is the need to recover the activating agent and also the generated liquid waste may require pretreatment before discharge (Yang et al., 2010).

Interestingly, the applications of microwave irradiation in the production and regeneration of activated carbon have grown considerably. Basically, in the microwave irradiation, interior heat is generated as a result of the dipole rotation and ionic conduction of the char particles under the application of a high-frequency voltage (Basta et al., 2009; Hesas et al., 2015). The applied field or potential voltage induces a change in particles orientation thereby synchronizing its agitation which amounted to the interior heat (Saucier et al., 2015). More importantly, this interior-heat significantly facilitates heat transfer and uniform distribution, hence, redeeming energy consumption and char activation period. Nevertheless, microwave irradiation heating has been applied in the preparation (Guo et al., 2008) and modifications (Coss and Cha, 2000; Ania et al., 2004; Nabais et al., 2004; Ania et al., 2005) of activated carbon. Even though, the essential literature on the significant effect on colour adsorption performance remains very scarce. In view of this highlight, microwave irradiation was used to pretreat chemically activated coconut shell and utilized for POME decolourisation at selected treatment factors which include $\mathrm{pH}$, adsorbent dosage and contact time. The surface chemistry of the microwave pretreated CS-MW and non-pretreated CS-raw was characterized using the $\mathrm{pH}$ at the point of zero charges. In addition, the surface morphology and elemental analysis of the absorbents were examined using the Scanning Electron Microscopy (SEM) and Energy Dispersive X-ray (EDX). The equilibrium data of the adsorption process were evaluated by fitting to Freundlich and Langmuir isotherms models to determine the adsorption mechanism of the pollutant molecules.

\section{Materials and methods}

\subsection{Preparation of POME and activated carbon}

About $20 \mathrm{~L}$ of final discharged POME was collected from a palm oil mill at Dengkil, Selangor, filtered to remove all the visible debris and stored in a chiller at $4^{\circ} \mathrm{C}$ temperature. A powdered chemically activated $(\mathrm{KOH})$ coconut shell carbon (CS-AC) was purchased from Merck, and this was regarded as CS-raw in this study. The CS-raw was washed thoroughly to attain a neutral $\mathrm{pH}$ value and also to get rid of all external impurities such as residual ash and remnant of the active reagent. Thereafter, the cleaned CS-raw was oven dried at $110^{\circ} \mathrm{C}$ for a period of $5 \mathrm{hrs}$ and sieved to obtained particles sizes between $0.5-1.0 \mathrm{~mm}$ using a sieve shaker. Finally, CS-raw was subjected to pretreatment using microwave heating at a low power of $100 \mathrm{~W}$ for a duration of 5 mins and the resulted microwave pretreated activated carbon was stored in an airtight container and labelled CS-MW.

\subsection{Characterization of activated carbon}

\subsubsection{Surface chemistry characterization}

The $\mathrm{pH}$ at the point of Zero Charge was used to 
characterize the surface chemistry of the CS-raw and CSMW. Nine samples of variable $\mathrm{pH}$ (1-9) were prepared by a $0.05 \mathrm{M}$ aqueous solution of $\mathrm{NaOH}$ or $\mathrm{HNO}_{3}$, while $\mathrm{NaNO}_{3}$ of $0.01 \mathrm{M}$ concentration was applied as the electrolyte at the background (Song et al., 2010). Then, $20 \mathrm{~mL}$ of the prepared solutions were collected into a conical flask and $0.1 \mathrm{~g}$ of the absorbents was added to each of the samples. In all, a total of 18 samples were prepared and placed in a swing agitator at $130 \mathrm{rpm}$ and average room temperature of $298 \mathrm{~K}$ for $48 \mathrm{hrs}$. Afterwards, the carbon was filtered, and the equilibrium $\mathrm{pH}$ of the samples was measured.

\subsubsection{CS-AC morphology and elemental analysis}

Scanning electron microscopy (SEM) (Hitachi S3400 N) Scanning Electron Microscope) was used to identify the surface physical morphology. The BrunauerEmmett-Teller (BET) surface area and pore volume of the adsorbents were measured by multi-point BET from $\mathrm{N}_{2}$ adsorption isotherms, using Automated Gas Sorption System (Quanta chrome Instruments).

\subsection{Analytical method}

The chemical parameters such as colour, chemical oxygen demand (COD), ammonia $\left(\mathrm{NH}_{3}\right)$ total phosphorus (TP), and $\mathrm{pH}$ of the POME were determined using standard procedure (APHA., 2005) as presented in Table 1. The colour determination was carried out by following the platinum-cobalt standard method 8025 at a wavelength of $890 \mathrm{~nm}$ using $\mathrm{HACH}$ spectrophotometer (DR 4000U). The COD, $\mathrm{NH}_{3}$, and TP were determined using appropriate reagents. The $\mathrm{pH}$ value of the POME was determined using a digital $\mathrm{pH}$ meter.

Table 1. Physicochemical properties of the POME before and after adsorption at best condition

\begin{tabular}{ccccc}
\hline Parameter & Unit & $\begin{array}{c}\text { DOE } \\
\text { standard* }\end{array}$ & $\begin{array}{c}\text { Before } \\
\text { adsorption }\end{array}$ & $\begin{array}{c}\text { After } \\
\text { adsorption }\end{array}$ \\
\hline Color, C & ADMI & 100 & 260 & 13 \\
COD & $\mathrm{mg} / \mathrm{L}$ & 1000 & 1264 & 972 \\
$\mathrm{pH}$ & --- & $4-9$ & 8.5 & 2.0 \\
$\mathrm{TSS}$ & $\mathrm{mg} / \mathrm{L}$ & 200 & 1540 & 523 \\
Ammonia & $\mathrm{mg} / \mathrm{L}$ & 20 & 3273 & 2634 \\
\hline
\end{tabular}

* Source: Din (2017)

The effects of the three variables were investigated; $\mathrm{pH}$, adsorbent dosages (AD) and contact time (CT). The $\mathrm{pH}$ was varied up to 5 different levels $(2,3,4,6$, and 8.5), AD 6 different levels $(1,2,3,4,5,6 \mathrm{~g})$ and $\mathrm{CT}$ was varied to 8 different levels (1, 2, 3, 4, 5, 6, 7 and $8 \mathrm{hrs})$. In each of the treatment equal volume of $100 \mathrm{~mL}$ sample (POME) was used under constant agitation of $50 \mathrm{rpm}$. At the end of each treatment, the final colour was determined using a $\mathrm{HACH}$ spectrophotometer (DR 4000U). The amount of colour removal was determined using equation 1 for each of the corresponding adsorption treatment.

$$
\text { Color Removal }(\%)=\frac{\left(c_{0}-c_{e}\right)}{c_{n}} \times 100 \%
$$

Where $\mathrm{C}_{\mathrm{o}}(\mathrm{ADMI})$ is the initial concentration of colour and $\mathrm{C}_{\mathrm{e}}(\mathrm{ADMI})$ is the residual colour concentration

\subsection{Adsorption Isotherm}

Adsorption isotherm was used to quantify the amount of adsorbate (colour removed) on the adsorbent as a function of colour concentration at a constant temperature. The application is based on the normalizing the quantity of colour adsorbed by the mass of the adsorbent and this ensures comparison with Isotherm models. In this study, Langmuir and Freundlich Isotherm Models were applied to the experimental data.

\subsubsection{Langmuir adsorption isotherm}

The Langmuir model assumes that uptake of colour occurs on a homogenous surface by monolayer adsorption without any interaction between adsorbed materials. Essentially, the greater values of $R^{2}$ indicate the relevance of the adsorption model for pollutants removal in POME. The value of $R_{L}$ between 0 and 1 indicates that the isotherm is favourable. The isotherm is unfavorable if $R_{L}>1$, linear if $R_{L}=1$, irreversible if $R_{L}=$ 0 and favorable if $R_{L}$ is between 0 to 1 . Mathematically, the Langmuir isotherm model is represented in equation 2:

$$
\begin{aligned}
& \frac{c_{e}}{q_{e}}=\frac{1}{Q_{n}} C_{e}+\frac{1}{Q_{n} b} \\
& R_{L}=\frac{1}{1+b C_{n}}
\end{aligned}
$$

Where $C_{e}$ refers to POME colour at equilibrium (ADMI); $q_{e}(\mathrm{mg} / \mathrm{g})$ is the amount of adsorbed pollutants; $Q_{o}(\mathrm{mg} / \mathrm{g})$ is the adsorption capacity related to complete monolayer coverage; $b(\mathrm{~L} / \mathrm{g})$ Langmuir constant; $C_{o}$ is the POME initial colour (ADMI); and $b$ and $Q_{o}$ were obtained from the slope and intercept respectively.

\subsubsection{Freundlich adsorption isotherm}

Freundlich isotherm model was used to consider the non-uniform distribution on the absorbent surface, which is the heterogeneity in the adsorption process. The extent of correlation between solution concentration and adsorption depends on the adsorption intensity, $n$. The adsorption can be linear $(\mathrm{n}=1)$, chemical $(\mathrm{n}<1)$, and favorable physical process $(\mathrm{n}>1)$. The $n$ and $K_{F}$ are Freundlich constant and they were obtained from the graph (Figure 4(b)) as the slope and intersection respectively. Mathematically, the Freundlich isotherm model is represented in equation 4

$$
\log q_{e}=\log K_{F}+\frac{1}{n} \log C_{e}
$$




\section{Results and discussion}

\subsection{Initial POME characterization}

Table 1 shows the initial physicochemical characteristic of POME. The results obtained exceeded the standard limits of Department of Environment Malaysia (DOE). The results revealed that the discharged POME contain $3273 \mathrm{mg} / \mathrm{L}$ of ammonia and $1264 \mathrm{mg} / \mathrm{L}$ of COD which far above the standard limits. Also, colour content with a concentration of 260 ADMI was observed as against the standard limit of $100 \mathrm{mg} / \mathrm{L}$ and also the qualities of the POME after adsorption at best treatment conditions were as displayed in Table 1.

\subsection{Characterization of microwave irradiated activated carbon}

\subsection{1 $\mathrm{pH}$ of the point of zero charge $\left(\mathrm{pH}_{\mathrm{pzc}}\right)$}

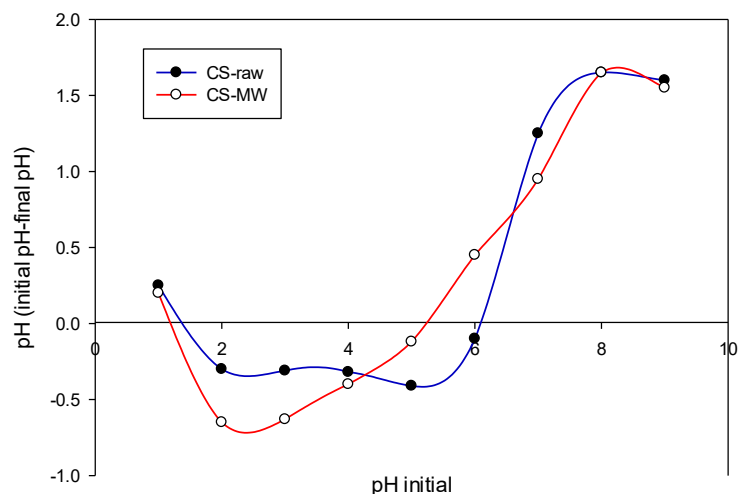

Figure 1. $\mathrm{pH}$ at point of zero charges for CS-raw (blue curve) and CS-MW (red curve)

The point of zero charges was determined to characterize the surface chemistry of the microwave pretreated (CS-MW) and non-pretreated (CS-raw) activated carbon. Based on Figure 1, the $p H_{p z c}$ at the point where the change in $\mathrm{pH}$ (initial $\mathrm{pH}$-final $\mathrm{pH}$ ) equal to 0 for the CS-MW and CS-raw where 5.3 and 6.2, respectively. More so, it is observed that the surface of the pretreated CS-MW is most negatively charged at $\mathrm{pH}$ 2.3 with the intensity of $(-0.73)$ while the non-pretreated was at 5.5 with $(-0.43)$ intensity, as presented in Figure 1. This implies that the precursor CS-raw had higher $p H_{p z c}$ compare to the pretreated CS-MW. Essentially, the decrease in the $p H_{p z c}$ indicates an increase in the acidic oxygen functional groups on the surface of the CS-MW (Song et al., 2010). Based on the previous research, the decrease in the $p H_{p z c}$ is as a result of the presence of the carboxyl, phenolic and carbonyl functional group on the surface of the adsorbent (Song et al., 2010; Li et al., 2011; Foo and Hameed, 2012). They further confirmed that these functional groups comprise the source of surface acidity. In other words, It can be deduced that the precursor (CS-raw) has a higher amount of basic sites, hence exhibit basic characteristic by adsorbing $\mathrm{H}^{+}$from the solution. Whereas, the pretreated CS-MW with acidic characteristic and lower $p H_{p z c}$ readily releases $\mathrm{H}^{+}$to form net negatively charged surface. This feature promotes swift adsorption of the adsorbate ions or colour from the sample.

\subsubsection{Scanning electron microscopy (SEM)}

SEM compared the physical changes on the surface of absorbents before and after microwave pretreatment. Figure 2(a) and (b) presents the surface morphology of the non-pretreated CS-raw and pretreated CS-MW, respectively. In Figure 2(a), a rougher surface with fewer cleavages and pores were observed. However, cleavages and pore size distribution are very important physical characteristic for the adsorption process. Also, good or uniform distribution of pores sizes which may include micro-pores, mesopores and macro-pores expedite sorption process (Ghani et al., 2017). As can be seen in Figure 2(b), more gravy surfaces with a high degree of pores of variable sizes are prominent. This can be attributed to the microwave irradiation treatment of the adsorbent which resulted in creating an enabling platform for effectual removal of adsorbate (Ghani et al., 2017).

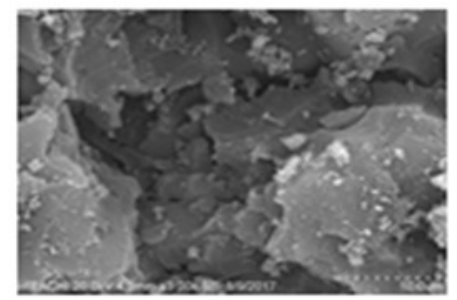

\section{CS-Raw}

(a)

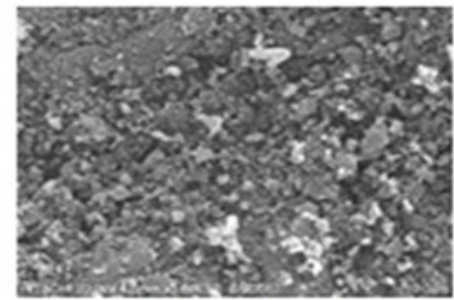

CS-MW

(b)
Figure 2. SEM image of the (a) non-pretreated coconut shell (CS-raw) and, (b) microwave irradiated coconut shell (CSMW) activated carbon at X3000 magnification

The microwave at $100 \mathrm{~W}$ increased the interior temperature of the precursor to a quasi-stationary level due to the induced change in the particles orientation and agitation (Ahmed, 2016). The author further reported that the generated heat gradually increased the interior temperature of the precursor to a quasi-stationary level. This method of heat generation ensures uniform distribution within the precursor and activation process, thus expediting the releasing of the volatile constituted substances such as the $\mathrm{CO}_{2}$ and $\mathrm{CO}$. This phenomenon increases the acidic oxygen-containing groups on the surface of the CS-MW. Morphologically, the releasing of the volatile matter accounted for the surface metamorphosis (Ghani et al., 2017), as well as the creation of more active sites (carbon). This process amounted to the formation of more uniformly distributed micropores, as depicted in Figure 2. This observation was further confirmed from the results of the BET surface analysis, as presented in Table 3. From Table 3, a 
considerable increase in the surface area and pores volume in the pretreated CS-MW. The specific surface area and the pore volume were observed increased by $11.88376 \%$ and $11.12867 \%$ respectively, after the microwave pretreatment. The improvement in the BET surface area was due to the oxidization effect which resulted in the releasing of volatile constituted substances, thus the formation uniform distributed pore structures on the surface (Liu et al., 2009; Zheng et al., 2014; Faraji and Ani, 2015).

\subsubsection{Energy dispersive X-ray (EDX)}

The EDX test conducted reveal the elemental constitutions and distribution both in the pretreated CSMW and non-pretreated CS-raw activated carbon. Table 2 present the elemental analysis of the non-pretreated CS -raw and pretreated CS-MW activated carbon. The elements of untreated CS-raw include C, O, Al, Si and, $\mathrm{S}$, while the element observed in the microwave pretreated CS-MW were C, O, Si and S. From Table 2, it is obvious that $\mathrm{Al}$ element completely disappeared after the microwave pretreatment, and also $\mathrm{O}, \mathrm{Si}$ and $\mathrm{S}$ weight composition reduces significantly. This indicates that chemical reactions took place during the pretreatment. Precisely, the oxidation process greatly influences the availability of $\mathrm{C}$ active sites, as well as the structural reformation of the adsorbent (Wang et al., 2006; Liu et al., 2010). This implies that the oxidation process of the carbonaceous precursor accounted for the reduction in the weight composition of the trace elements ( $\mathrm{Si}$ and $\mathrm{S}$ ), and also the formation of more acidic oxygen-containing functional groups on the surface (Song et al., 2010; Ghani et al., 2017). These processes play a key role in the formation of more active sites for efficient adsorption process.

Table 2. Elemental analysis of activated carbon

\begin{tabular}{lccccc}
\hline \multirow{2}{*}{ Activated carbon } & \multicolumn{5}{c}{ Elemental analysis (wt\%) } \\
\cline { 2 - 6 } & $\mathrm{C}$ & $\mathrm{O}$ & $\mathrm{Al}$ & $\mathrm{Si}$ & $\mathrm{S}$ \\
\hline CS-raw & 84.42 & 8.56 & 0.39 & 4.81 & 1.82 \\
Pretreated & 91.56 & 4.57 & - & 3.49 & 0.38 \\
CS-MW & & & & &
\end{tabular}

\subsubsection{BET surface area and pores volume analysis}

BET surface area and pores volume analysis for both CS-MW and CS-raw activated carbon were conducted using $\mathrm{N}_{2}$ adsorption with Micrometric 3Flex Version 1.02 model and the detailed results are presented in Table 3. Based on Table 3, the surface area of the CSraw was $562.5786 \mathrm{~m}^{2} / \mathrm{g}$ while the CS-MW activated carbon was determined to be $629.4341 \mathrm{~m}^{2} / \mathrm{g}$. This shows that the BET surface area increased by $11.88376 \%$ after the microwave pretreatment. Similarly, a considerable increment was observed in the total pore volume with $11.12867 \%$ and $9.231679 \%$ for the adsorption and desorption after the microwave pretreatment, respectively. In addition, the average pore diameters show a noticeable change after the microwave irradiation pretreatment, as substantiated in Table 3.

Table 3. Summary of the BET analysis for both activated carbon: pretreated (CS-MW) and non-pretreated (CS-raw)

\begin{tabular}{lccc}
\hline \multicolumn{1}{c}{ Parameters } & CS-MW & CS-raw & \% increment \\
\hline $\begin{array}{l}\text { BET Surface Are } \\
\left(\mathrm{m}^{2} / \mathrm{g}\right)\end{array}$ & 629.4341 & 562.5786 & 11.88376 \\
$\begin{array}{l}\text { Adsorption total } \\
\text { pore volume } \\
\left(\mathrm{cm}^{3} / \mathrm{g}\right)\end{array}$ & 0.850101 & 0.764970 & 11.12867 \\
$\begin{array}{l}\text { Desorption total } \\
\text { pore volume } \\
\left(\mathrm{cm}^{3} / \mathrm{g}\right)\end{array}$ & 0.850101 & 0.778255 & 9.231679 \\
$\begin{array}{l}\text { Adsorption } \\
\text { average pore }\end{array}$ & 51.3208 & 48.6132 & 5.569681 \\
$\begin{array}{l}\text { diameter }(\AA) \\
\begin{array}{l}\text { Desorption } \\
\text { average pore } \\
\text { diameter }(\AA)\end{array}\end{array}$ & 51.3208 & 49.4574 & 3.767687 \\
\hline
\end{tabular}

3.3 Effect of $p H$ and contact time (CT) on decolourisation of POME using microwave irradiated activated carbon (pretreated CSAC)

Figure 3(a) illustrates the profile of $\mathrm{pH}$ effect and contact time on the percentage removal of colour. Principally, microwave irradiated CS activated carbons exhibited amphoteric features under variable $\mathrm{pH}$ which directly influence the surface positivity or negativity of the adsorbent particles (Laine et al., 1989; Tan et al., 2008 Lim et al., 2010; Cazetta et al., 2011). The pH value was varied from 8.5 to 2 and at higher value (basic $\mathrm{pH}$ ), anionic functional group become prominent and not suitable for the adsorption of negatively charged color causative molecules due to interionic repulsion between similarly charged particles (Mohammed and Chong, 2014; Pathania et al., 2017) As can be seen in Figure 3 (a), adsorption of colour increases with decrease in $\mathrm{pH}$ value and this phenomenon is associated not only with the negative charge on the surface of the adsorbent but also with excess $\mathrm{OH}^{-}$ions in the solution that compete for the adsorption sites. This observation was in agreement with the previous findings on the use of activated carbon to decolourize POME (Ahmad et al., 2005; Mohammed and Chong, 2014; Alkhatib et al., 2015). It is obvious that the color removal percentage increased from $78 \%$ to $95 \%$ with a decrease in $\mathrm{pH}$ values from 8.5 to 2 . In addition, the decrease in $\mathrm{pH}$ caused a significant enhancement of the adsorption capacity of colour. Also, decolourisation rate increases progressively with increase in CT (Mohammed and Chong, 2014), but steady rate of color removal was observed after $5 \mathrm{hrs}$ of contact. From Figure 3(a) the maximum colour removal at $\mathrm{pH} 2$ was observed at $5 \mathrm{hrs} \mathrm{CT}$ while the highest 


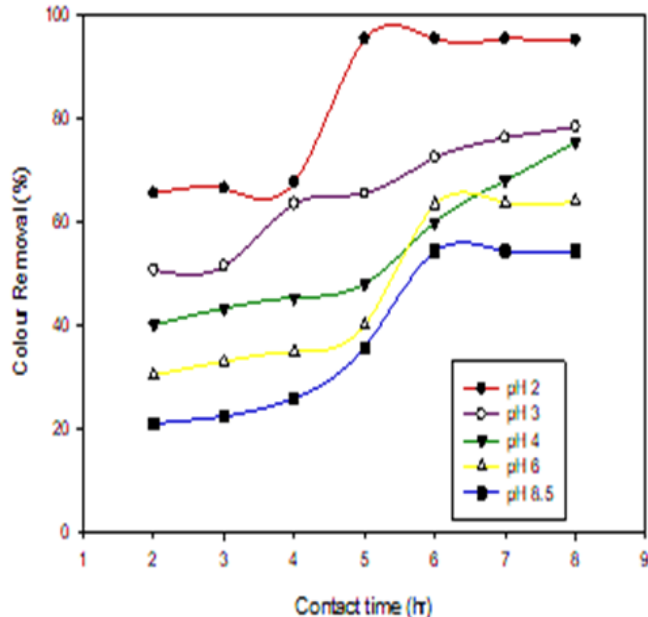

(a)

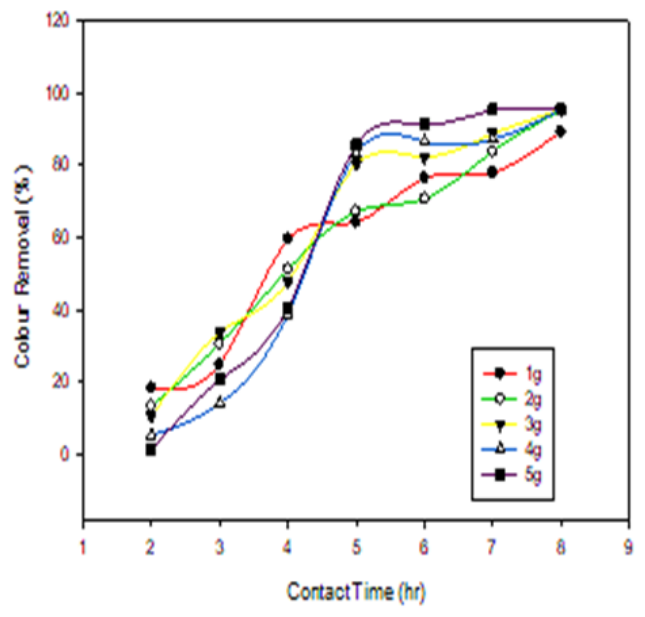

(b)

Figure 3. POME decolourisation under variable contact time at different (a) $\mathrm{pH}$, and (b) dosage

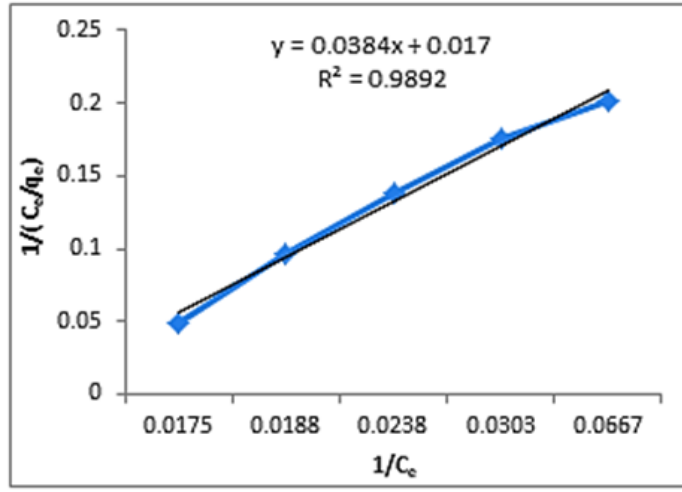

(a)

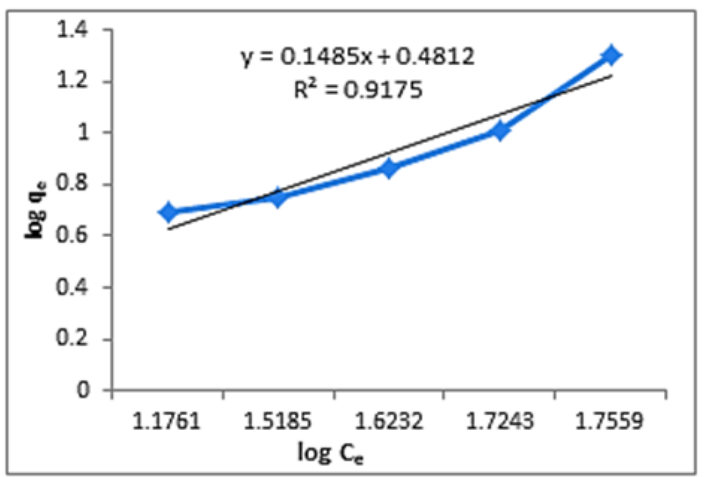

(b)

Figure 4. Adsorption Isotherm plot of (a) Langmuir; $1 /\left(C_{e} / q_{e}\right) v s 1 / C_{e}$ and (b) Freundlich; $\log q_{e} v s \log C_{e}$

decolourisation at $\mathrm{pH} 8.5$ was obtained after $7 \mathrm{hr}$ CT.

Effect of adsorbent dosage (AD) and CT on decolourisation using microwave irradiated pretreated CS-MW

Figure 3 (b) presents the effect of variable dosage of CS-MW at varied CT. The highest colour removal was obtained at an $\mathrm{AD}$ of $5 \mathrm{~g} / 100 \mathrm{~mL}$ with $95 \%$ decolourisation. It was observed that the percentage of colour removal at equilibrium state increased from $89 \%$ to $95 \%$ when $\mathrm{AD}$ increases from 1 to $5 \mathrm{~g}$. The results clearly indicate that the removal efficiency increases to an optimum value at an adsorbent dosage of $5 \mathrm{~g}$ above which further increase in adsorbent dosage has no significant effect on it. The trend of these results is in agreement with the previous findings (Gobi and Vadivelu, 2013; Alkhatib et al., 2015). This could be explained by the fact that the adsorption equilibrium has been reached. Also, the percentage of colour removal increased with increase in $\mathrm{CT}$ for all the adsorbent dosage $1 \mathrm{~g}$ to $6 \mathrm{~g}$. As the CT increase from $1 \mathrm{hr}$ to $8 \mathrm{hrs}$, the percentage of colour removal increases. The maximum percentage of colour removal for $5 \mathrm{~g}$ of CSMW occurs at $7 \mathrm{hrs}$.

\subsection{Adsorption isotherm}

The equilibrium colour removal and adsorption characterization were examined using Langmuir and Freundlich Isotherm model. A straight line obtained from $\log q_{e}$ vs $\log C_{e}$ plot gives the slope $(1 / \mathrm{n})$ values of 0.148 , which indicated their favourable adsorption using pretreated CSAC at the experimental conditions, as shown in Figure 4(b). The strong correlation was observed between the experimental data and the Langmuir isotherm model with $\mathrm{R}^{2}$ of 0.989 (Figure 4(a)). This implies that the adsorbed colour was homogeneously distributed on the pretreated CSAC surface as per the assumption made for the application of the Langmuir equation, which confirms the homogeneity of the CS-MW (Alkhatib et al., 2015; Pathania et al., 2017). Also, a very good correlation was obtained between the experimental data and Freundlich model with $\mathrm{R}^{2}$ of 0.917 . Though, the coefficient of determinant archived with the Langmuir isotherm was slightly higher. In overall, the results obtained are satisfactory because of the strong agreements between the experimental data and the models. This finding is in an agreement with the previous study reported by Alkhatib et al. (2015). 


\section{Conclusion}

In this work, Coconut shell-Activated Carbon was pre-treated with the microwave irradiation and applied to decolourize POME under the varied effect of $\mathrm{pH}, \mathrm{AD}$ and CT. POME decolourisation is strongly influenced by $\mathrm{pH}, \mathrm{AD}$ and $\mathrm{CT}$. The decolourisation increases with a decrease in $\mathrm{pH}$ and increase in CT. Though, after the optimal CT of $5 \mathrm{hrs}$, a steady rate of decolourisation was observed at increasing AD. The optimum condition for best decolourisation of $95 \%$ was found at $\mathrm{pH}$ of $2,5 \mathrm{~g}$ $\mathrm{AD}$ and $5 \mathrm{hrs}$ CT. In addition, the Langmuir Isotherm Model was found favourable with an $\mathrm{R}^{2}$ value of 0.989 . Therefore, the microwave irradiation pre-treated adsorbent is expected to be feasible for the colour removal from Palm Oil Mill Effluent.

\section{Acknowledgement}

The authors express their appreciation to the Universiti Putra Malaysia for providing financial support to conduct this study (Grant Putra Impak (IPB), Vot: 9530900).

\section{References}

Adeleke, A.O., Latiff, A.A.A., Al-Gheethi, A.A. and Daud, Z. (2017). Optimization of operating parameters of novel composite adsorbent for organic pollutants removal from POME using response surface methodology. Chemosphere, 174, 232-242. https://doi.org/10.1016/j.chemosphere.2017.01.110

Ahmad, A.L., Sumathi, S. and Hameed, B.H. (2005). Adsorption of residue oil from palm oil mill effluent using powder and flake chitosan: Equilibrium and kinetic studies. Water Research, 39(12), 2483-2494. https://doi.org/10.1016/j.watres.2005.03.035

Ahmed, M.J. (2016). Application of agricultural based activated carbons by microwave and conventional activations for basic dye adsorbtion: Review. Journal of Environmental Chemical Engineering, 4 (1), 89-99. https://doi.org/10.1016/ j.jece.2015.10.027

Alkhatib, M.F., Mamun, A.A. and Akbar, I. (2015). Application of response surface methodology (RSM) for optimization of color removal from POME by granular activated carbon. International Journal of Environmental Science and Technology, 12(4), 1295 -1302. https://doi.org/10.1007/s13762-014-0504-4

Amosa, M.K., Jami, M.S., Alkhatib, F.R. and Tajari, T. (2016). Turbidity and suspended solids removal from high- strength wastewater using high surface area adsorbent: Mechanistic pathway and statistical analysis. Cogent Engineering, 3(1). https:// doi.org/10.1080/23311916.2016.1162384
Ania, C.O., Menéndez, J.A., Parra, J.B. and Pis, J.J. (2004). Microwave-induced regeneration of activated carbons polluted with phenol. A comparison with conventional thermal regeneration. Carbon, 42(7), 1377-1381. https://doi.org/10.1016/ j.carbon.2004.01.010

Ania, C.O., Parra, J.B., Menéndez, J.A. and Pis, J.J. (2005). Effect of microwave and conventional regeneration on the microporous and mesoporous network and on the adsorptive capacity of activated carbons. Microporous and Mesoporous Materials, 85(1-2), 7-15. https://doi.org/10.1016/ j.micromeso.2005.06.013

APHA (2005) Standard methods for the examination of water and waste water, $21^{\text {st }}$ ed. Washington, DC: American Public Health Association.

Azmi, N.S. and Yunos, K.F. (2012). Turbidity and Suspended Solid Reduction from Oil Mill Effluent Using Coconut Shell Charcoal. International Conference on Agricultural and Food Engineering for Life (Cafei 2012), 26-28 November 2012, p. 496503. Malaysia: UPM

Baranitharan, E., Khan, M.R., Prasad, D.M.R., Teo, W.F.A., Tan, G.Y.A. and Jose, R. (2015). Effect of biofilm formation on the performance of microbial fuel cell for the treatment of palm oil mill effluent. Bioprocess and Biosystems Engineering, 38(1), 1524. https://doi.org/10.1007/s00449-014-1239-9

Basta, A.H., Fierro, V., El-Saied, H. and Celzard, A. (2009). 2-Steps KOH activation of rice straw: An efficient method for preparing high-performance activated carbons. Bioresource Technology, 100(17), 3941-3947. https://doi.org/10.1016/ j.biortech.2009.02.028

Cazetta, A.L., Vargas, A.M.M., Nogami, E.M., Kunita, M.H., Guilherme, M.R., Martins, A.C., Silva, T.L., Moraes, J.C.G. and Almeida, V.C. (2011). NaOHactivated carbon of high surface area produced from coconut shell: Kinetics and equilibrium studies from the methylene blue adsorption. Chemical Engineering Journal, 174(1), 117-125. https:// doi.org/10.1016/j.cej.2011.08.058

Coss, P.M. and Cha, C.Y. (2000). Microwave regeneration of activated carbon used for removal of solvents from vented air. Journal of the Air and Waste Management Association, 50(4), 529-535. https://doi.org/10.1080/10473289.2000.10464038

Demirbas, A. (2008). Heavy metal adsorption onto agrobased waste materials: A review. Journal of Hazardous Materials, 157(2-3), 220-229. https:// doi.org/10.1016/j.jhazmat.2008.01.024

Din, A.K. (2017). Malaysian Oil Palm Industry Performance 2016 and Prospects for 2017. Retrieved 
from http://www.mpob.gov.my/images/stories/ pdf/2017/2017_Dr.KushairiPALMEROS2017.pdf

Embrandiri, A., Quaik, S., Rupani, P., Srivastava, V. and Singh, P. (2015). Sustainable utilization of oil palm wastes: Opportunities and Challenges. In Singh, R.P. and Sarkar, A. (Eds.) Waste Management, p. 217232. New York, USA: Nova Science Publishers

Faraji, S. and Ani, F.N. (2015). The development supercapacitor from activated carbon by electroless plating - A review. Renewable and Sustainable Energy Reviews, 42, 823-834. https:// doi.org/10.1016/j.rser.2014.10.068

Foo, K.Y. and Hameed, B.H. (2012). Coconut husk derived activated carbon via microwave induced activation: Effects of activation agents, preparation parameters and adsorption performance. Chemical Engineering Journal, 184, 57-65. https:// doi.org/10.1016/j.cej.2011.12.084

Gautam, R.K., Mudhoo, A., Lofrano, G. and Chattopadhyaya, M.C. (2014). Biomass-derived biosorbents for metal ions sequestration: Adsorbent modification and activation methods and adsorbent regeneration. Journal of Environmental Chemical Engineering, 2(1), 239-259. https://doi.org/10.1016/ j.jece.2013.12.019

Ghaedi, M., Sadeghian, B., Pebdani, A.A., Sahraei, R., Daneshfar, A. and Duran, C. (2012). Kinetics, thermodynamics and equilibrium evaluation of direct yellow 12 removal by adsorption onto silver nanoparticles loaded activated carbon. Chemical Engineering Journal, 187, 133-141. https:// doi.org/10.1016/j.cej.2012.01.111

Ghani, Z.A., Yusoff, M.S., Zaman, N.Q., Zamri, M.F.M.A. and Andas, J. (2017). Optimization of preparation conditions for activated carbon from banana pseudo-stem using response surface methodology on removal of color and COD from landfill leachate. Waste Management, 62, 177-187. Ltd. https://doi.org/10.1016/j.wasman.2017.02.026

Gobi, K. and Vadivelu, V.M. (2013). By-products of palm oil mill effluent treatment plant - A step towards sustainability. Renewable and Sustainable Energy Reviews, 28, 788-803. https:// doi.org/10.1016/j.rser.2013.08.049

Guo, J. and Lua, A. (2003). Preparation of activated carbons from oil palm-stone chars by microwaveinduced carbon dioxide activation. Carbon, 38(14), 1985-1993.

Hashim, Z., Subramaniam, V., Harun, M.H. and Kamarudin, N. (2017). Carbon footprint of oil palm planted on peat in Malaysia. The International Journal of Life Cycle Assessment, 23(6), 1201-1217. https://doi.org/10.1007/s11367-017-1367-y
Hoseinzadeh Hesas, R., Arami-Niya, A., Wan Daud, W.M.A. and Sahu, J.N. (2015). Microwave-assisted production of activated carbons from oil palm shell in the presence of $\mathrm{CO}_{2}$ or $\mathrm{N}_{2}$ for $\mathrm{CO}_{2}$ adsorption. Journal of Industrial and Engineering Chemistry, 24, 196-205. https://doi.org/10.1016/ j.jiec.2014.09.029

Ibrahim, I., Hassan, M.A., Abd-Aziz, S., Shirai, Y., Andou, Y., Othman, M.R., Mohd Ali, A.A. and Zakaria, M. R. (2017). Reduction of residual pollutants from biologically treated palm oil mill effluent final discharge by steam activated bioadsorbent from oil palm biomass. Journal of Cleaner Production, 141, 122-127. https:// doi.org/10.1016/j.jclepro.2016.09.066

Kismir, Y. and Aroguz, A.Z. (2011). Adsorption characteristics of the hazardous dye Brilliant Green on Sakli\{dotless\}kent mud. Chemical Engineering Journal, 172(1), 199-206. https://doi.org/10.1016/ j.cej.2011.05.090

Laine, J., Calaft, A. and Labady, M. (1989). Preparation and characterization of activated carbons from coconut shell impregnated with phosphoric acid. Carbons, 27(2), 191-195.

Li, L., Liu, S. and Liu, J. (2011). Surface modification of coconut shell based activated carbon for the improvement of hydrophobic VOC removal. Journal of Hazardous Materials, 192(2), 683-690. https:// doi.org/10.1016/j.jhazmat.2011.05.069

Lim, W.C., Srinivasakannan, C. and Balasubramanian, N. (2010). Activation of palm shells by phosphoric acid impregnation for high yielding activated carbon. Journal of Analytical and Applied Pyrolysis, 88(2), 181-186. https://doi.org/10.1016/j.jaap.2010.04.004

Liu, C., Tang, Z., Chen, Y., Su, S. and Jiang, W. (2010). Bioresource Technology Characterization of mesoporous activated carbons prepared by pyrolysis of sewage sludge with pyrolusite. Bioresource Technology, 101(3), 1097-1101. https:// doi.org/10.1016/j.biortech.2009.09.012

Liu, G., Ma, J., Li, X. and Qin, Q. (2009). Adsorption of bisphenol A from aqueous solution onto activated carbons with different modification treatments. Journal of Hazardous Materials, 164(2-3), 12751280. https://doi.org/10.1016/j.jhazmat.2008.09.038

Mohammed, R.R. and Chong, M.F. (2014). Treatment and decolorization of biologically treated Palm Oil Mill Effluent (POME) using banana peel as novel biosorbent. Journal of Environmental Management, 132, 237-249. https://doi.org/10.1016/ j.jenvman.2013.11.031

Nabais, J.M.V., Carrott, P.J.M., Carrott, M.M.L.R. and Menéndez, J.A. (2004). Preparation and modification 
of activated carbon fibres by microwave heating. Carbon, 42(7), 1309-1314. https://doi.org/10.1016/ j.carbon.2004.01.033

Neoh, C.H., Yung, P.Y., Noor, Z.Z., Razak, M.H., Aris, A., Md Din, M.F. and Ibrahim, Z. (2017). Correlation between microbial community structure and performances of membrane bioreactor for treatment of palm oil mill effluent. Chemical Engineering Journal, 308, 656-663. https:// doi.org/10.1016/j.cej.2016.09.063

Othman, M.R., Hassan, M.A., Shirai, Y., Baharuddin, A. ., Ali, A.A.M. and Idris, J. (2014). Treatment of effluents from palm oil mill process to achieve river water quality for reuse as recycled water in a zero emission system. Journal of Cleaner Production, 67, 58-61. https://doi.org/10.1016/j.jclepro.2013.12.004

Parthasarathy, S., Mohammed, R.R., Fong, C.M., Gomes, R.L. and Manickam, S. (2016). A novel hybrid approach of activated carbon and ultrasound cavitation for the intensification of palm oil mill effluent (POME) polishing. Journal of Cleaner Production, 112, 1218-1226. https:// doi.org/10.1016/j.jclepro.2015.05.125

Pathania, D., Sharma, S. and Singh, P. (2017). Removal of methylene blue by adsorption onto activated carbon developed from Ficus carica bast. Arabian Journal of Chemistry, 10, S1445-S1451. https:// doi.org/10.1016/j.arabjc.2013.04.021

Saeed, M.O., Azizli, K., Isa, M.H. and Bashir, M.J.K. (2015). Application of CCD in RSM to obtain optimize treatment of POME using Fenton oxidation process. Journal of Water Process Engineering, 8, e7-e16. https://doi.org/10.1016/j.jwpe.2014.11.001

Saucier, C., Adebayo, M.A., Lima, E.C., Cataluña, R., Thue, P.S., Prola, L.D.T., Puchana-Rosero, M.J., Machado, F.M., Pavan, F.A. and Dotto, G.L. (2015). Microwave-assisted activated carbon from cocoa shell as adsorbent for removal of sodium diclofenac and nimesulide from aqueous effluents. Journal of Hazardous Materials, 289, 18-27. https:// doi.org/10.1016/j.jhazmat.2015.02.026

Song, X., Liu, H., Cheng, L. and Qu, Y. (2010). Surface modification of coconut-based activated carbon by liquid-phase oxidation and its effects on lead ion adsorption. Desalination, 255(1-3), 78-83. https:// doi.org/10.1016/j.desal.2010.01.011

Subramaniam, M.N., Goh, P.S., Lau, W J., Tan, Y.H., $\mathrm{Ng}$, B.C. and Ismail, A.F. (2017). Hydrophilic hollow fiber PVDF ultrafiltration membrane incorporated with titanate nanotubes for decolourization of aerobically-treated palm oil mill effluent. Chemical Engineering Journal, 316, 101110. https://doi.org/10.1016/j.cej.2017.01.088
Sumathi, S., Chai, S.P. and Mohamed, A.R. (2008). Utilization of oil palm as a source of renewable energy in Malaysia. Renewable and Sustainable Energy Reviews, 12(9), 2404-2421. https:// doi.org/10.1016/j.rser.2007.06.006

Tabassum, S., Zhang, Y. and Zhang, Z. (2015). An integrated method for palm oil mill effluent (POME) treatment for achieving zero liquid discharge - A pilot study. Journal of Cleaner Production, 95, 148155. https://doi.org/10.1016/j.jclepro.2015.02.056

Tan, I.A.W., Ahmad, A. L. and Hameed, B.H. (2008). Adsorption of basic dye on high-surface-area activated carbon prepared from coconut husk: Equilibrium, kinetic and thermodynamic studies. Journal of Hazardous Materials, 154(1-3), 337346. https://doi.org/10.1016/j.jhazmat.2007.10.031

Tan, S.P., Kong, H.F., Bashir, M.J.K., Lo, P.K., Ho, C.D., and Ng, C.A. (2017). Treatment of palm oil mill effluent using combination system of microbial fuel cell and anaerobic membrane bioreactor. Bioresource Technology, 245, 916-924. https:// doi.org/10.1016/j.biortech.2017.08.202

Tee, P.F., Abdullah, M.O., Tan, I.A.W., Mohamed Amin, M.A., Nolasco-Hipolito, C. and Bujang, K. (2016). Performance evaluation of a hybrid system for efficient palm oil mill effluent treatment via an air-cathode, tubular upflow microbial fuel cell coupled with a granular activated carbon adsorption. Bioresource Technology, 216, 478-485. https:// doi.org/10.1016/j.biortech.2016.05.112

Wang, Z., Zhou, J., Wang, Q., Fan, J. and Cen, K. (2006). Thermodynamic equilibrium analysis of hydrogen production by coal based on $\mathrm{Coal} / \mathrm{CaO} /$ $\mathrm{H} 2 \mathrm{O}$ gasification system. International Journal of Hydrogen Energy, 31(7), 945-952. https:// doi.org/10.1016/j.ijhydene.2005.07.010

Williams, H.M. and Parkes, G.M. B. (2008). Activation of a phenolic resin-derived carbon in air using microwave thermogravimetry. Carbon, 46(8), 11691172. https://doi.org/10.1016/j.carbon.2008.04.011

Yang, K., Peng, J., Srinivasakannan, C., Zhang, L., Xia, H. and Duan, X. (2010). Preparation of high surface area activated carbon from coconut shells using microwave heating. Bioresource Technology, 101 (15), 6163-6169. https://doi.org/10.1016/ j.biortech.2010.03.001

Zheng, C., Zhou, X., Cao, H., Wang, G. and Liu, Z. (2014). Synthesis of porous graphene/activated carbon composite with high packing density and large specific surface area for supercapacitor electrode material. Journal of Power Sources, 258, 290-296.

https://doi.org/10.1016/

j.jpowsour.2014.01.056 